\title{
TECTONIC ENVIRONMENTS AND RARE METAL MINERALIZATION IN PEGMATITES OF KOMU AREA, SOUTHWESTERN NIGERIA
}

\section{ADEMUYIWA ADETUNJI AND OJOK O. OCAN}

(Received 22 October 2008; Revision Accepted 01, March 2010)

\begin{abstract}
The discrimination diagrams: $\mathrm{Rb}$ versus $\mathrm{Nb}+\mathrm{Y}$ and $\mathrm{Nb}$ versus $\mathrm{Y}$, and $\mathrm{Th} / \mathrm{Ta}$ ratio combined with field observations and empirical information from the literature were used to infer the tectonic environments and sources of the rare metal mineralization in the pegmatites of Komu area, southwestern Nigeria.

The discrimination diagrams show that the pegmatites were mainly emplaced in tectonic environments similar to those of syn-collisional granites (Syn COG) and within plate granites (WPG). Volcanic arc environment was not pronounced. The emplacement of the pegmatites was structurally controlled by the predominantly Northeast (NE)Southwest (SW) and North northeast (NNE)-South southwest (SSW) fault systems that were developed during the Pan-African orogeny. The upwelling of the mantle at the beginning and faulting systems associated with the active and closing stages of the Pan-African orogeny elevated rare metals from the mantle to higher crustal levels where they were incorporated into the pegmatitic fluids.

The $\mathrm{Th} / \mathrm{Ta}$ ratios of less than 1.00 which resemble that of the oceanic ridge tectonic environment is attributable to the upwelling of mantle material. The variation in the tectonic environments of the pegmatites may be attributed to the long span of the Pan-African orogeny (750-450 Ma).
\end{abstract}

KEY WORDS: Komu. Nigeria. Pegmatites. Rare metals. Tectonic environments.

\section{INTRODUCTION}

In the last sixty years, studies of the Nigerian rare metal occurrence have established two distinct episodes of mineralization. The younger of these is the predominantly columbite-cassiterite mineralization associated with the anorogenic Mesozoic granite of central Nigeria. The older episode is tantalite-columbitecassiterite mineralization associated with pegmatites of the main phase granite magmatism of the Pan-African orogeny $(600 \pm 150 \mathrm{Ma})$. Most studies on these pegmatites were focused on the petrology, mineralization trends and factors that governed the degree of mineralization. Published work on the tectonic environments and sources of rare metals mineralization in the pegmatites is scarce.

On the basis of structural observations alone, Evans (1987) interpreted the occurrence of tin belts of different epochs in the margin of Atlantic as indicative of sources of rare metals from either upper mantle / or lower crust. In sharp contrast to these observations, Wright (1970) suggested that pegmatite mineralization must have been leached from continental rocks by hydrothermal fluids ejected from Pan-African magmatism. The Rb-Sr isochron age of $185-183 \mathrm{Ma}$ on biotite from pegmatites of Egbe was earlier thought to indicate a possible link between the pegmatites and Mesozoic granite (Matheis and Caen-Vachettee, 1983). This could not be supported by further chemical and field data which established a genetic link between the pegmatites and Pan-African granites (Matheis, 1987; Kuster, 1990).
The spatial association of the pegmatites of Kushaka area and the Pan-African transcurrent fault was established by Garba (2002). Inferences on the sources of rare metal have been from information deduced from radioactive isotopes and structural observations. The principal aim of this work is to use the available data: the chemical data presented in this paper and information derived from literature to infer the tectonic environments of the pegmatites and sources of their rare metal mineralization.

\section{REGIONAL GEOLOGICAL SETTING}

Komu is part of the geological terrane referred to as the basement complex of southwestern Nigeria. The basement complex forms an important domain of the Pan-African mobile belt east of West African craton, south of Tuareg shield and northwest of Congo craton. The mobile belt extends from the Hoggar through Air, Adrar des Iforas and Gourma (Algeria) to the Dahomeyides in Ghana, Togo, Benin, Nigeria and Cameroon. The Dahomeyide fold belt constitutes the southern portion of the mobile belt. From the southeastern margin of West African craton eastwards, three major tectonic domains are present: the Voltain foreland basin with sedimentary sequences, the Beninian thrust and fold belt; and the Nigerian high grade migmatite-gneiss terrane.

The rocks in the Voltain basin rest unconformably on the shield and progressively folded and metamorphosed westwards. The Beninian thrust and fold belt have two main structural units: the

Ademuyiwa Adetunji Department of Applied GeologySchool of Earth and Mineral Sciences Federal University of Technology, P.M.B. 704, Akure, Ondo State, Nigeria.

Ojok O. Ocan Department of Geology Obafemi Awolowo University, lle Ife, Nigeria. 
Buem an Atacora. The Buem is southwestward dipping, largely consists of unmetamrophosed sandstones, shales and mudstones. The Buem unit is well developed in Ghana. The Atacora unit consists of quartzite, micaschists, phyllite, basaltic volcanics and marble. The internal unit attained a high pressure metamorphic grade in southern part of Togo where kyanite eclogite is present.

The Nigerian Nigerian sector consists of two main areas: the Beninian gneisses and migmatite-gneiss (Figure 1). The gneisses are of high grade amphibolite facies and predominantly consist of quartzo-feldspathic and anatectic migmatitic granitoids. The

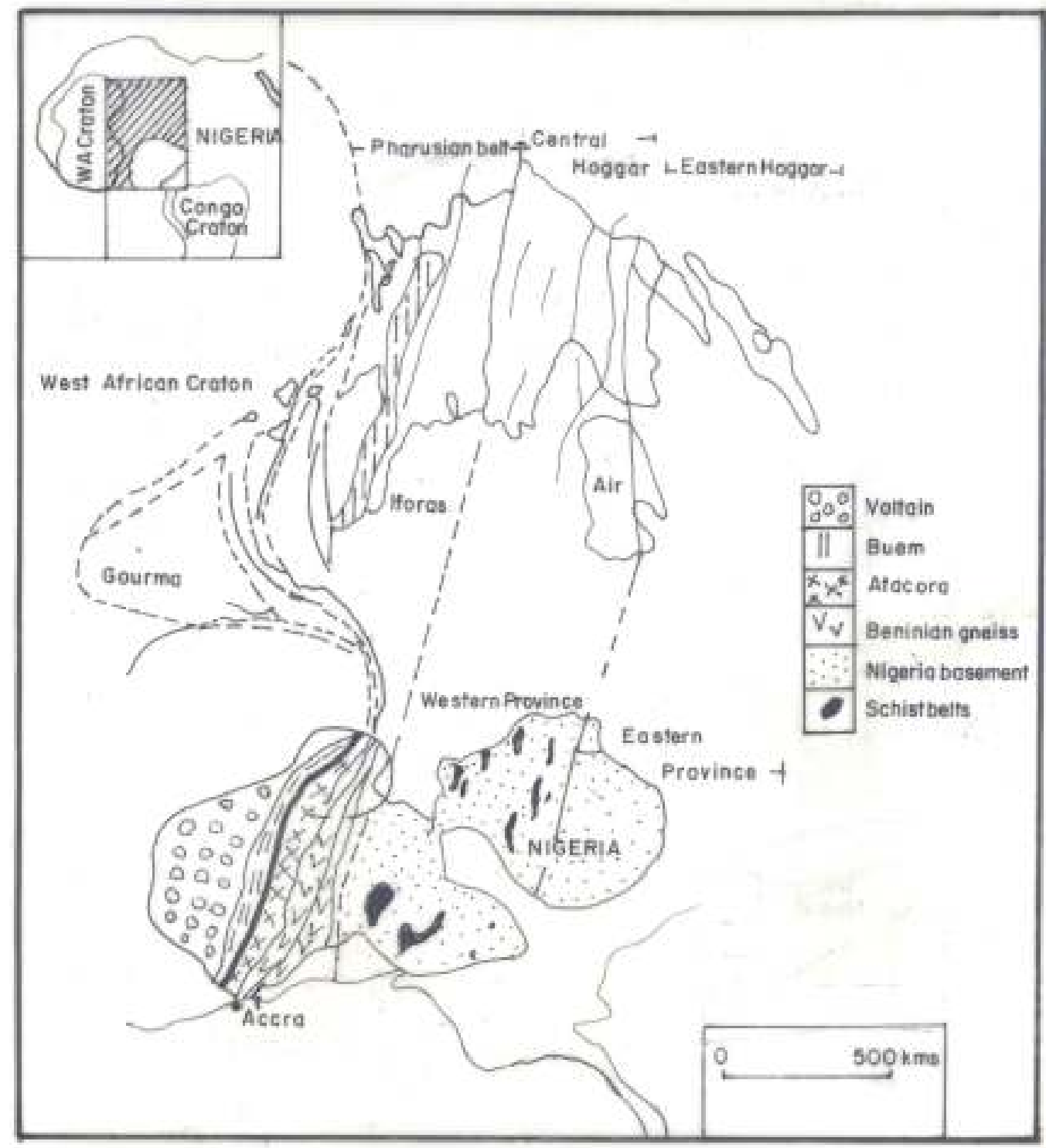

Figure 1: Geological map of Pan-African belt east of West African craton (After Caby et al., 1981)

migmatite-gneiss complex consists of Archean polycyclic grey gneisses of granodioritic to tonalitic composition. The entire mobile belt east of West African craton is divided into six petrological zones (Affaton et al., 1991).

Plate tectonics models have been used to explain the evolution of this Pan-African belt. Burke and Dewey (1973) suggested that Dahomeyide fold belt evolved from the closure of an Atlantic Ocean type by continent-continent collision between passive western continent of Birrimia and active eastern continent of Dahomea. Continental fragmentation commenced in ca
$1100 \mathrm{Ma}$ and by ca $900 \pm 100 \mathrm{Ma}$ a paleo-ocean had developed east of the West African craton. The closure of the ocean began with subduction processes operating along an eastward dipping Benioff Zone. This was marked by widespread calc-alkaline volcanisms which are similar to those of modern day island arcs and active continental margins (Affaton et al., 1991). Behind the possible Pan-African arc were several often fault bound Pan-African volcano-sedimentary sequences which latter evolved to schist belts.

Locally, the study area is part of Iseyin-Oyan river schist belt. Adetunji (2004) observed that the 
pegmatites of Komu area are hosted by three distinct petrologic units: medium to high grade pelitic gneisses, low pressure amphibolites and granitic rocks. The distribution of these rocks is shown in Figure 2. The granites do not form any remarkable topographic feature, but occur as dykes of not more than $10 \mathrm{~m}$ wide and $15 \mathrm{~m}$ long. On the basis of silicate mineralogy and textural characteristics, the rocks in the pegmatite suites are grouped into graphic granite, blocky alkali feldspar pegmatite, quartz-albite-muscovite-tourmaline pegmatites and fine-grained saccharroidal albitemuscovite-tourmaline-garnet rock (Adetunji and Ocan, 2010). The graphic granite and alkali

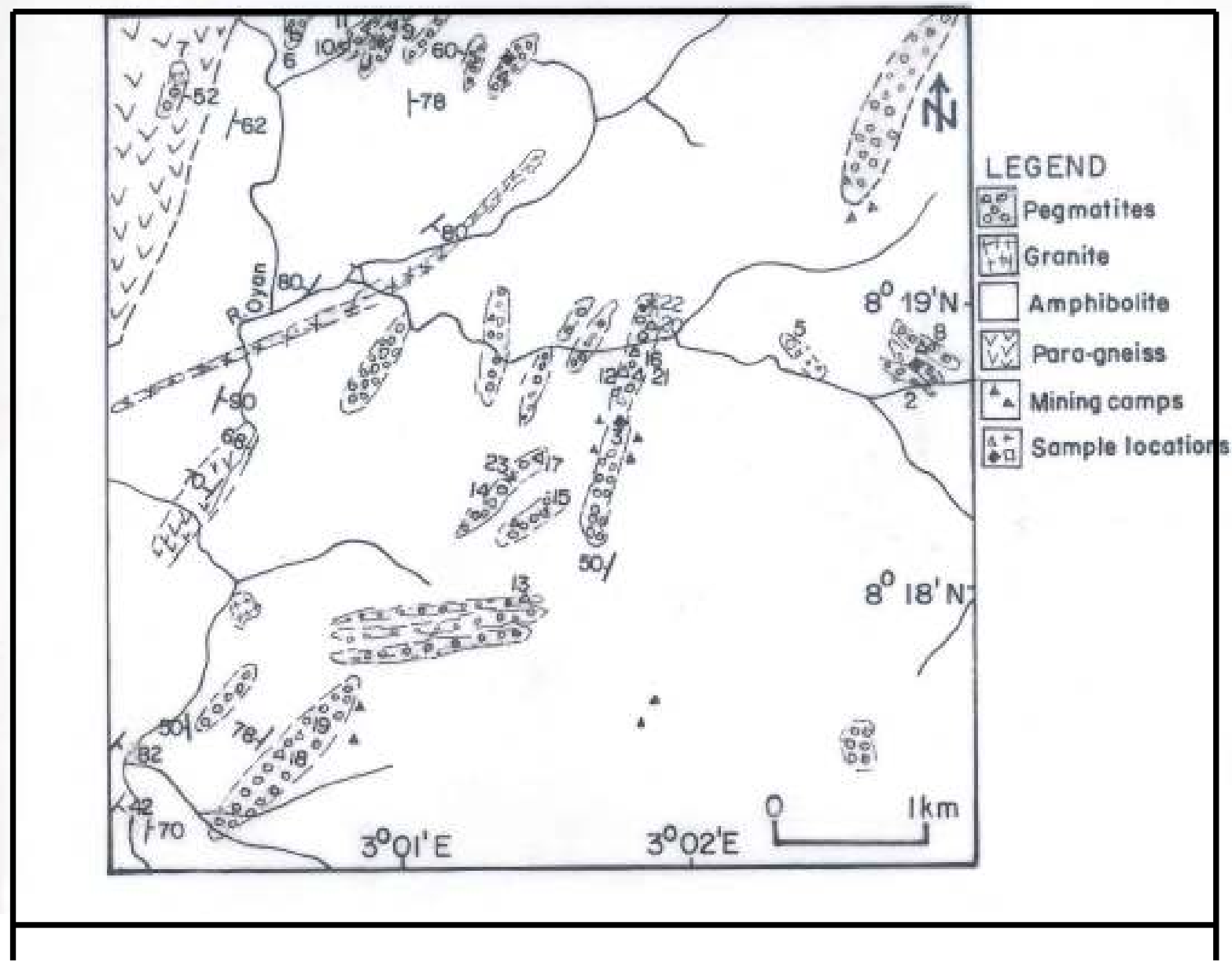

Figure 2: Geological of Komu area (After Adetunji (2004)

feldspar pegmatite occur as autoliths in the quartzalbite-muscovite-tourmaline pegmatites. The finegrained rock appears to intrude the other types of pegmatite.

\section{MATERIALS AND METHODS}

Twenty three whole rock pegmatite samples were analyzed for some elemental compositions using the Energy Dispersive X- Ray Fluorescence Photospectrometer at the Centre for Energy Research and Training, Ahmadu Bello University, Zaria, Nigeria.

Annular $25 \mathrm{mCi}{ }^{109} \mathrm{Cd}$ and ${ }^{55} \mathrm{Fe}$ excitation sources were used. The ${ }^{109} \mathrm{Cd}$ emits $\mathrm{Ag}-\mathrm{K}$ X-rays (22.1 $\mathrm{Kev}$ ) and ${ }^{55} \mathrm{Fe}$ emits $\mathrm{Mn}-\mathrm{K}$ X-rays $(5.89 \mathrm{Kev})$. These allowed the detection of elements with low characteristics excitation energies. The calibration and standardization of the equipment were done according to procedures described by Funtua (1999). The interpretation of chemical data was done by plotting them on relevant discrimination diagrams

\section{RESULTS}

The relevant elemental compositions and $\mathrm{Th} / \mathrm{Ta}$ ratios of the pegmatites are presented in Table 1 . In the Figure 3 , the plot of $\mathrm{Rb}$ versus $\mathrm{Nb}+\mathrm{Y}$ contents is shown on the discrimination diagram of Pearce et al. (1984). The graphic granite and the alkali feldspar pegmatite (autoliths) wholly plot in the field of granites formed in syn-collisional environment (Syn COG), the quartzalbite-muscovite-tourmaline pegmatite spreads over the fields of granite formed in syn-collisional, volcanic arc (VAG) and within plate (WPG) tectonic environments while the fine-grained rock plots solely in the field of granite formed in ocean ridge tectonic environment (ORG).

In the Figure 4, the plot of $\mathrm{Nb}$ versus $\mathrm{Y}$ contents is shown on tectonic environment discrimination diagram 
of Pearce et al. (1984). The graphic granite and alkali feldspar pegmatite (autoliths) plot in the (VAG+ Syn
COG) and WPG environments while the quartz-albitemuscovite-tourmaline pegmatites plot in the WPG,

Table 1: Some chemical compositions of pegmatites of Komu area, Oyo State, southwestern Nigeria. (concentrations in ppm)

\begin{tabular}{|l|l|l|l|l|l|l|l|l|}
\hline Pegmatite & $\mathrm{Rb}$ & $\mathrm{Nb}$ & $\mathrm{Y}$ & $\mathrm{Ta}$ & $\mathrm{Th}$ & $\mathrm{K} \times 10^{6}$ & $\mathrm{Th} / \mathrm{Ta}$ & $\mathrm{Nb}+\mathrm{Y}$ \\
\hline 1 & 2430 & 8 & 35 & 169 & 79 & 17.50 & 0.47 & 43 \\
\hline 2 & 430 & 8 & 11 & 141 & 18 & 15.98 & 0.13 & 19 \\
\hline 3 & 1700 & 41 & 27 & 148 & 24 & 14.66 & 0.16 & 68 \\
\hline 4 & 1310 & 7 & 15 & 147 & 22 & 15.05 & 0.15 & 22 \\
\hline 5 & 293 & 6 & 10 & 129 & 19 & 10.79 & 0.15 & 16 \\
\hline 6 & 569 & 6 & 13 & 123 & 22 & 14.03 & 0.18 & 19 \\
\hline 7 & 1340 & 13 & 18 & 143 & 29 & 12.72 & 0.20 & 31 \\
\hline 8 & 29 & 7 & 10 & 122 & 16 & 2.86 & 0.13 & 17 \\
\hline 9 & 69 & 12 & 9 & 123 & 19 & 1.62 & 0.16 & 21 \\
\hline 10 & 574 & 62 & 17 & 104 & 15 & 6.40 & 0.14 & 79 \\
\hline 11 & 387 & 72 & 9 & 118 & 66 & 4.12 & 0.56 & 81 \\
\hline 12 & 137 & 78 & 8 & 97 & 14 & 0.98 & 0.15 & 86 \\
\hline 13 & 657 & 30 & 14 & 113 & 23 & 3.70 & 0.20 & 44 \\
\hline 14 & 454 & 36 & 10 & 122 & 26 & 4.96 & 0.21 & 46 \\
\hline 15 & 219 & 90 & 8 & 135 & 15 & 15.18 & 0.11 & 98 \\
\hline 16 & 340 & 22 & 31 & 166 & 32 & 9.32 & 0.19 & 53 \\
\hline 17 & 297 & 36 & 8 & 102 & 14 & 1.75 & 0.14 & 44 \\
\hline 18 & 447 & 63 & 13 & 96 & 13 & 3.56 & 0.14 & 76 \\
\hline 19 & 275 & 83 & 9 & 102 & 16 & 2.54 & 0.16 & 92 \\
\hline 20 & 805 & 110 & 17 & 105 & 16 & 5.42 & 0.15 & 127 \\
\hline 21 & 199 & 73 & 7 & 153 & 13 & 1.80 & 0.09 & 80 \\
\hline 22 & 16 & 72 & 15 & 168 & 24 & 2.22 & 0.14 & 87 \\
& & & & & & & & \\
\hline 23 & 13 & 54 & 11 & 146 & 23 & 3.12 & 0.16 & 65 \\
\hline
\end{tabular}

1-4: blocky alkali feldspar pegmatite, 5-6: graphic granite, 7-21: quartz-albite-muscovite-tourmaline pegmatite, 22-23: fine-grained albite-muscovite-tourmaline-garnet rock.

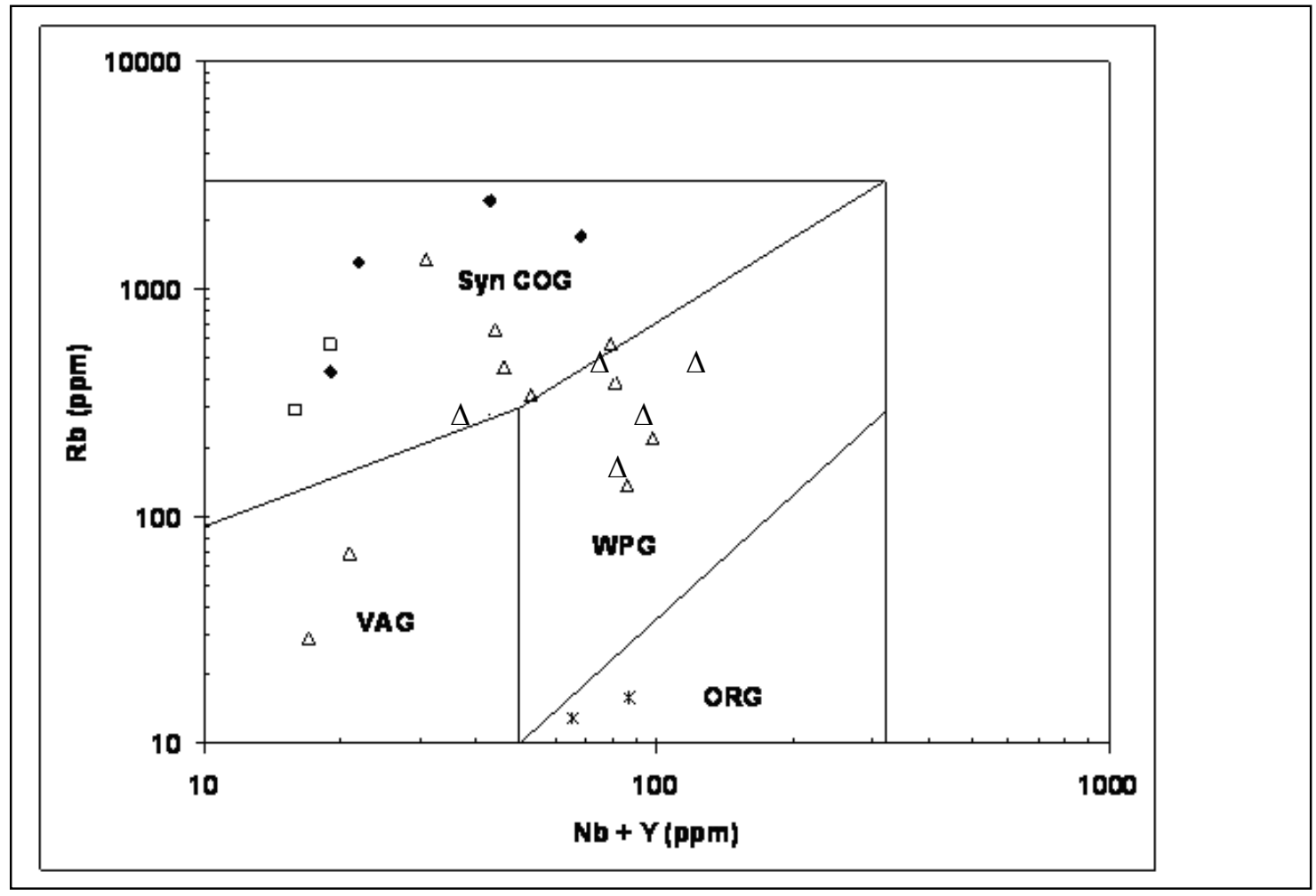

Figure 3: Plot of $\mathrm{Rb}$ vs. $\mathrm{Nb}+\mathrm{Y}$ (after Pearce et al., 1984) 
- alkali feldspar pegmatite; $\square$ graphic granite; $\Delta$ quartz-albite-muscovite-tourmaline pegmatite; $\%$ fine grained albitemuscovite-tourmaline-garnet rock. WPG: within Plate Granite; VAG: Volcanic Arc Granite; SynCOG: Syn Collisional Granite; ORG: Ocean Ridge Granite

AORG: anorogenic, VAG + Syn COG environments. The fine-grained rock wholly plots in the WPG environment. DISCUSSION

The chemical data presented in this study form part of the first author's M.Sc thesis research work. The $\mathrm{Th} / \mathrm{Ta}$ ratios and the discrimination diagrams were used to infer the tectonic environments of the pegmatites at the time of their emplacement and sources of their rare metals mineralization. The use of $\mathrm{Th} / \mathrm{Ta}$ ratio for interpreting tectonic environment has long been employed for both volcanic and plutonic rocks. According to

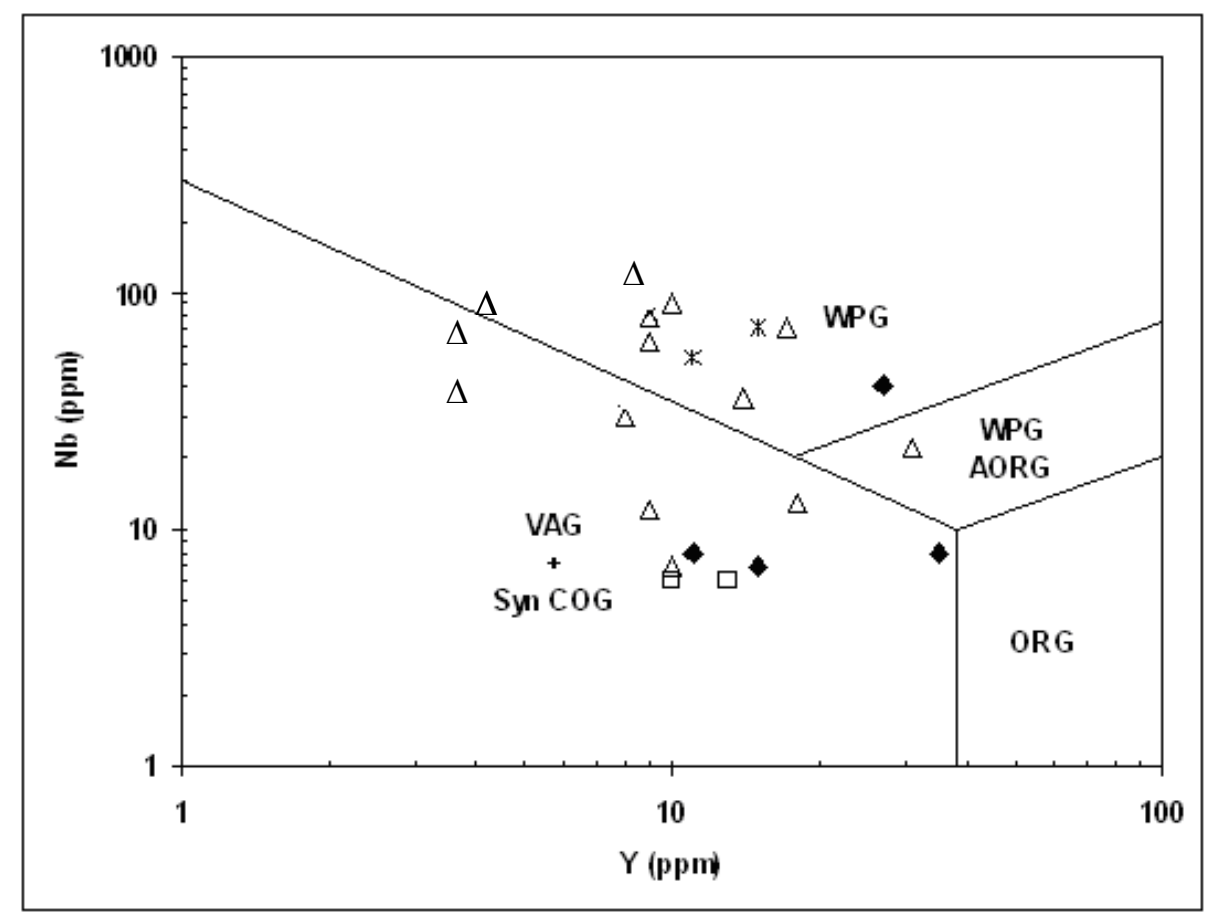

Figure 4: Plot of Nb vs. Y (after Pearce et al., 1984); AORG: Anorogenic Granite, others as defined in Figure 3.

Schandl and Gorton (2002), the Th/Ta ratios for different tectonic environments are summarized as follows: midoceanic ridge $-<1.0)$, within plate $(2.0-6.0)$, active continental margin (6.0-20.0) and oceanic arc (20.075.0). It is apparent from the Th/Ta ratios alone that the tectonic environment of the pegmatites of Komu area is close to that of mid oceanic-ridge. The $\mathrm{Th} / \mathrm{Ta}$ ratio for any tectonic environment depends on the degree of incompatibility between $\mathrm{Th}$ and $\mathrm{Ta}$, and it may either represent the involvement of a subducting slab in magma generation (Pearce and Peat, 1995), recycling of subducted sedimentary rocks (Hawkesworth et al., 1997) or crustal build up of the sialic component of arc through time (Lentz, 1998). The pegmatites of Komu area show a general depletion of Th and were not emplaced in volcanic arc and oceanic ridge environments (Figure 3). Complex tectonic units that include accretional prisms, magmatic arcs, marginal basins, thrust belts, suture zones and ophiolites have been mapped and reconstructed in the Pan African mobile belt east of West African craton (Affaton et al., 1991). At the initial stage of the Pan-African orogeny, mafic and ultramafic rocks were emplaced as a result of crustal thinning (Bafor, 1988). The protoliths of the amphibolites in the study area are part of these early mafic intrusives that accompanied Pan-African orogeny. The upwelling of mafic magma (Dada and Rahaman, 1995) continued toward the end of crustal thickening that accompanied the orogeny. This invariably involved the replacement of the old lithospheric mantle by shallow convective asthenosphere (Caby and Boese, 2001).

The parental granites of the pegmatites of Komu area were produced from either melting induced by contact of mafic magma with crustal rocks, fractional crystallization of the mafic magma or crustal thickening associated with subduction. In the subduction episodes, various elements ascended from the upper mantle and enriched the crust directly above the subduction zone (Martin and De Vito, 2005). There is also important input from the lower crust where there is melting, assimilation and hybridization. The rare metals deposited in these pegmatites were probably introduced from the lower crust and mantle-derived materials rather than leaching 
from the country rocks as advocated by authors like Matheis and Caen-Vachettee (1983). The closing stages of Pan African orogeny were marked by series of transcurrent faults (Kuster, 1990, Garba, 2002). Therefore, mantle and lower crust materials may have risen to higher crustal levels through these deep seated fault systems. This is apparently responsible for the $\mathrm{Th} / \mathrm{Ta}$ ratios of mid-oceanic ridge environment. Evidently, the alignment of the pegmatites in almost NNE-SSW and NE-SW as shown in Figure 2 indicates that the fault systems had overbearing influence on the emplacement of the pegmatites.

Adetunji (2004) suggested the possible presence of pegmatites of niobium yttrium fluorine (NYF) family in the area. This type of pegmatite is associated with anorogenic magmatism (Cerny, 1991). If the Himalayan type collision theory advocated for the evolution of the region were to be true, the likelihood of extensional fault system for the lifting up of magma after orogenic collapse could not be ruled out. This may have served as source of the melt that produced NYF imprints in the pegmatites. This also gives anorogenic environment signature (Figure 4). Martin and Devito (2005) noted that a rift related anorogenic granite from which NYF pegmatites may be emplaced immediately after (or during transtensional situation) a protracted period of orogeny. These authors reported the association of potassic rocks (e.g. syenites) and some NYF pegmatites in a terrane dominated by lithium cesium tantalum (LCT) pegmatites in Pan-African mobile belt of Anjanabooina, Madagascar. It is suggested that the area experienced an episode of rifting and anorogenic activity relatively soon after the termination of Pan-African orogeny. Pezzota (2005) attributed the source of NYF pegmatites in that part of Madagascar to the syenitic plutons emplaced during the post orogenic rifting and magmatism. The 570-540 Ma age of the syenites falls within the Pan-African orogeny. The syenite plutons in areas not too far from the study area may have been emplaced immediately after orogenic collapse in a similar manner to those of Madagascar. In the Brazilian sector of the Pan-African mobile belt where similar analogous rare element pegmatites have been identified, Kaul and Cordiani (2000) reconstructed three tectonic regimes during the Pan-African orogeny. Sequentially, these are compressive and two transtensive tectonic regimes. The ascents of magmatic melts were through large scale fracture systems developed during these tectonic regimes.

In conclusion, due to the long span of the PanAfrican orogeny (750-450 Ma), different tectonic environments came into play during which pegmatitic melts were produced. Rare metals were essentially derived from mantle and lower crust; and elevated to higher crustal levels through mantle upwelling and deep seated fault systems. The high contents of $\mathrm{Rb}, \mathrm{Nb}, \mathrm{Zr}$ and $Y$, coupled with the possible presence of pegmatites of NYF family, show possible overlapping of felsic magmatic episodes of largely anorogenic and minor ones after the orogenic episode has subsided.
Acknowledgements

The authors are grateful to the anonymous reviewers whose comments helped to improve the quality of this article.

\section{REFERENCES}

Adetunji, A., 2004. An assessment of the economic potentials of the pegmatite bodies of Komu area, Oyo State, southwestern Nigeria. M.Sc. Thesis, Obafemi Awolowo University, Ile-Ife, Nigeria.

Adetunji, A. and Ocan, O.O., 2010. Characterization and mineralization potentials of pegmatites of Komu area, southwestern Nigeria. Resource Geology, 60 (1): 87-97 Online: Doi: 10.1111/j.1751.3928.2010.00116.x

Affaton, P., Rahaman, M.A., Trompetts, R. and Sougy, J., 1991. The Dahomeyide orogen:Tectonothermal evolution and relationships with the Volta basin. In R.D. Dallmeyer and J.F. Lecorche (Editors) The West African orogens and circum Atlantic correlatives. IUGS/UNESCO project 233, Springer, Berling Heidelberg, New York, pp. 107-122.

Baffor, B.E., 1988. Some geochemical considerations in the evolution of the Nigerian basement in the Egbe area of southwestern Nigeria. In Precambrian Geology of Nigeria. Geological Survey Nigeria Spec. Publ. pp. 277-288.

Burke, K.C and Dewey, J.F., 1973, An outline of the Precambrian plate development. In D.M. Tarling and S.K Runlovn (Editors) Implication of continental drift to Earth Sciences, Academic Press, London, pp. 1035-1045.

Caby, R., Bertrand. J.M.L. and Black, R. 1981, PanAfrican ocean closure and continental collision in the Hoggar-Iforas segment, central Sahara. In A. Kroner (Editor) Precambrian plate tectonics, Elsevier, Amsterdam, pp.407-434.

Caby, R. and Boesse, J.M., 2001, Pan-African nappee system in southwestern Nigeria, the Ife-llesa schist belt. J. Afri. Earth Sci. 33 (2): 211-225.

Cerny, P., 1991. Rare element granitic pegmatites, part 2: regional to global environments and petrogenesis. Geoscience Canada, 5 (18): 6881.

Dada, S.S. and Rahaman, M.A., 1995. Archean-Lower Proterozoic crustal evolution in Nigeria. Afri. Geosc. Review 2: 1-7.

Evans, A.M., 1987, An introduction to Ore Geology $2^{\text {nd }}$ edition Blackwell Publ Chichester Sussex, UK. 
Funtua, I.I. 1999. Analysis of $\mathrm{Nb}$-Ta ores by energy dispersive X-ray fluorescence spectrometry. Journal of Trace Microprobe Technology 17, No. 2, 189-195.

Garba, I., 2002. Late Pan-African tectonics and origin of $\mathrm{Au}$ mineralization and rare metal pegmatites in the Kushaka schist belt northwestern Nigeria. J. Min. Geol. 38 (1): 1-12.

Hawkesworth, C.J.,Turner, S.P., McDermott, F., Peat, D.W. and Calsteren, V., 1997, U- The isotopes in arc magmas: implications for element transfer from subduction crust. Sci. 276: 551-555.

Kuster, D., 1990. Rare metal pegmatites of Wamba, central Nigeria: their formation in relationships to late Pan-African granites. Mineral Deposita 25: 25-33.

Kaul,P.F.T., and Cordiani, U.G., 2000. Geochemistry of Serra do Mar granitoid magmatism and tectonic implications, southern Brazil. Revista Brasilera de Geosciencias 30 (1): 115-119.

Lentz, D.R., 1998. Trace element systematics of felsic volcanic rocks associated with massive sulphide deposits in the Bathurst mining camp: petrogenetic, tectonic and chemostratigraphic implications for VMS exploration. Geol. Assoc. Can. Short course notes 12: 359-402.

Martin, R.F. and Devito, C., 2005. The patterns of enrichment in felsic pegmatites Ultimately depend on tectonic setting. Can. Min. 43: 20272048.

Matheis, G., 1987. Nigeria rare metal pegmatites and their lithological framework. In Bowden, P. and Kinnaird, J.A. (Editors) African Geology Reviews, Geological Journal 22: 271-291.

Matheis, G. and Caen-Vachette, M., 1983. Rb- Sr isotopic study of rare metal bearing and barren pegmatites in the Pan-African reactivation zone of Nigeria. J. Afri. Earth Sci. 1: 35-40.

Pearce, J.A., Harris, N.B.W. and Tindle, A.G., 1984. Trace element discrimination diagrams for interpretation of granitic rocks. J. petrol. 25: 956983.

Pezzotta, F., 2005. A first attempt to the petrogenesis and the classification of granitic pegmatites of the Itremo region (central Madagascar). In Crystallization processes in granitic pegmatites, International Meeting (Elba), abstr. Vol. (www.elba-pegmatite.org)

Pearce, J.A. and Peate, D.W., 1995. Tectonic implications of the composition of volcanic Arc magmas: Annual reviews, Earth and Planetary Science 23: 251-285.
Schandl, E.S. and Gorton, M.P., 2002. Application of high field strength elements to discriminate tectonic settings in VMS environments. Econ. Geol. 97: 629-642.

Wright, J.B., 1970. Controls of mineralization in the older and younger tin fields of Nigeria. Econ. Geol. 65: $945-951$.

\section{Figure captions}

Figure 1: Geological map of Pan-African belt east of West African craton (after Caby et al.,. 1981).

Figure 2: Geology of the study area (after Adetunji, 2004):

Figure 3: plot of $\mathrm{Rb} \mathrm{Vs}$. $\mathrm{Nb}+\mathrm{Y}$ (after Pearce et al,. 1984) :

- alkali feldspar pegmatite; $\square$ graphic granite; $\Delta$ quartzalbite-muscovite-tourmaline pegmatite; $*$ fine grained albite-muscovite-tourmaline-garnet rock. WPG: within Plate Granite; VAG: Volcanic Arc Granite; SynCOG: Syn Collisional Granite; ORG: Ocean Ridge Granite

Figure 4: Plot of Nb vs. Y (after, Pearce et al., 1984); AORG: Anorogenic Granite, other symbols as defined in figure 3

\section{Table caption}

Table 1 some chemical compositions of pegmatites of Komu area, Oyo State, southwestern Nigeria (concentration in ppm): 1-4: blocky alkali feldspar pegmatite, 5-6: graphic granite, 7-21: quartz-albitemuscovite-tourmaline pegmatite, 22-23: fine-grained albite-muscovite-tourmaline-garnet rock 